\title{
Factor Affecting Participation in the Redd+ Program in the Central Region of Vietnam
}

\author{
Nguyen Dinh Tien ${ }^{1 *}$ and Roberto F Rañola ${ }^{2}$ \\ ${ }^{1}$ Center for Agricultural Research and Ecological Studies (CARES), Vietnam National University of Agriculture, Vietnam \\ ${ }^{2}$ College of Economics and Management, University of the Philippines Los Baños, The Philippines
}

Submission: January 18, 2017; Published: February 08, 2017

"Corresponding author: Nguyen Dinh Tien, Center for Agricultural Research and Ecological Studies (CARES), Vietnam National University of Agriculture, Vietnam, Tel: +84988 248 596; Email: nguyentiencares@gmail.com; ndtien.up@gmail.com ; rdranola@up.edu.ph

\begin{abstract}
The global deforestation, the main cause of global warming, is a major global concern. Reducing Emissions from Deforestation and Forest Degradation and enhancing carbon stock (REDD+) is a mechanism designed to provide financial rewards to forest owners and users. The study estimated the Willingness to Accept and determined the factors affecting the decision of local people to participate in the REDD+ program in Con Cuong district, Nghe An province, Vietnam. Results showed that the mean maximum WTA for a ton of carbon in the Con Cuong district is equivalent to $114,400 \mathrm{VND}$ or US $\$ 5.2 / \mathrm{tCO}$. On average, a hectare of forest can get 1,658,800 VND/ha or US\$75.5/ha/year from carbon sequestration. This would generate a social WTA per year of 22.9 billion VND or US\$ 1.04 million for a total of 3,341 households in the two communes in Con Cuong district. The factors affecting decision-making on participating in REDD+ include bid level of carbon price, age of respondent, sex, labour force, forest land areas, awareness of REDD+, and non-timber forest products income.
\end{abstract}

The study recommends that local people should be trained/provided information on forest protection, role of forest to local environment, carbon measuring and forest monitoring. Secondly, there is a need to establish a committee for REDD+ payment with participation of local villagers in payment process. Thirdly, the security of forestland tenure of individual households is very important for the effective implementation of REDD+. Local authorities should focus on determining the land tenure or rights of forestland owners within villages and communes.

Abbreviation: NFDS: The National Forest Development Strategy; PES: Payments for Ecosystem Services; WTA: Willingness to Accept; PFES: Payment for Forest Environmental Services; CVM: Contingent Valuation Method

\section{Introduction}

The global deforestation, the main cause of global warming, is a major global concern. The deforestation and forest degradation are estimated to contribute about 12 to 20 per cent of global emissions van der Werf, et al. [1] while natural forests can prevent and reduce greenhouse gas (GHG) emission (IPCC, 2007). Conserving tropical forests is one essential activity to stop climate change Komba \& Muchapondwa [2]. The need to reduce emissions from the forest sector has been noted by the Intergovernmental Panel on Climate Change [3].

Reducing Emissions from Deforestation and Forest Degradation and enhancing carbon stock (REDD+) is a mechanism designed to provide financial rewards to forest owners and users. The REDD+ mechanism that provides financial incentives to developing countries for protecting their forests can take account of payments to forest owners with rights over forests Luca, et al. [4]. If it is sensibly designed and effectively implemented, REDD+ can promote sustainable economic and social development and contribute to biodiversity conservation by restoring and protecting productive ecosystems.

The Vietnam government has recognized the role of forest sector and has developed a number of programs aimed at protecting and restoring its forests such as the National Forest Development Strategy (NFDS) and Payments for Ecosystem Services (PES) (GLOBE International, 2013). The objective of the Vietnamese government is to increase the forest cover of Vietnam from 39.7\% as reported in 2011 (MARD, 2011) to 45\% in 2020 (Decision 799 QD-TTg). The country's goal is to reduce by $20 \%$ the GHG emissions in the agricultural sector and by 19 million tons of $\mathrm{CO} 2 \mathrm{e}$ (CO2 equivalent) in 2020 through the reduction of deforestation and forest degradation REDD Vietnam [5]. Thus, REDD+ is considered as one of the important components of Vietnam's climate change mitigation efforts. 
Vietnam has established a National Readiness Management Arrangement, including a Vietnam REDD+ Steering Committee, Network and dedicated Office. It is also now drafting its National REDD+ Strategy. It is estimated that REDD+ can generate benefits of US\$ 80-100 million per year in the country, roughly three to four times the amount of aid money currently supporting the Vietnamese forestry sector. The REDD+ mechanism depends to a large extent on the carbon Prices and the resulting compensation paid for the avoided deforestation and degradation. Effective policies and payment for reduced $\mathrm{CO} 2$ emission from deforestation and forest degradation is considered one possible mechanism for the successful implementation of REDD+ Righelato \& Spracklen [6]. However, the effect of carbon prices on REDD+ has not been widely analyzed, and the few studies available show a wide range of results Angelsen, et al. [7]. Several studies using models of the carbon market have for simplicity assumed that carbon prices remain constant. The analysis of Sohngen \& Sedjo [8] showed how carbon prices could affect the extent of deforestation.

The North Central Region contains six provinces in the northern half of Vietnam's narrow central part. All provinces in this region stretch from the coast in the east to Laos in the west. The emission reduction program includes the north central region with 5.1 million hectare of which 4.33 million hectare is forestland. Thanh Hoa, Nghe An, Ha Tinh, Quang Binh, Quang Tri and Thua Thien Hue were the six provinces selected for the pilot REDD+ program (Vietnam UN-REDD). REDD+ target is not only intended to reduce deforestation and forest degradation but also to improve livelihoods and reduce poverty.

Central to the implementation of the mechanism is the ability to elicit an accurate estimation of willingness to accept (WTA) payment for individual households to change their use of land from low carbon sequestration to high carbon sequestration uses Samuel, et al. [9]. Analysis of willingness to accept (WTA) compensation can provide information on how to encourage forestland owners to participate in the conservation and forest protection program Henrik \& Yohei [10].

While there are a number of studies on REDD+ that were conducted in the pilot areas of Vietnam, none of these studies have looked into issues related to payment mechanisms for carbon sequestration that will be attractive enough to encourage forest owners to participate in the REDD+ program. In general, the study aimed to estimate the Willingness-to-Accept (WTA) payment for carbon level for the protection of forest with the REDD+ program; and determine the factors affecting the decision of local people to be involved in REDD+ program.

\section{Methodology}

\section{Conceptual framework}

The conceptual framework of the study is guided by the assumption underlying the valuation framework presented in (Figure 1). The framework defines the factors affecting the willingness to accept carbon payment for the REDD+ program in Vietnam. In a farm environment, there are a number of factors affecting the decision of farmers in allocating their resources. In general,forestland owners are likely to plant trees because this would provide additional benefits for them. Potential factors affecting the willingness to participate in REDD+ and WTA carbon payment of households in the study sites are the amount of payment that local people receive from PFES (payment for forest environmental services), the information about REDD+ that outsiders or local authorities can disseminate to local villagers, the length of fallow period that affects the amount of carbon sequestered by the forest, age of household head, sex of household head, educational level of household head, income from non-timber forest products, family labour, forestland areas, and level of awareness of REDD+ (Figure $1)$.

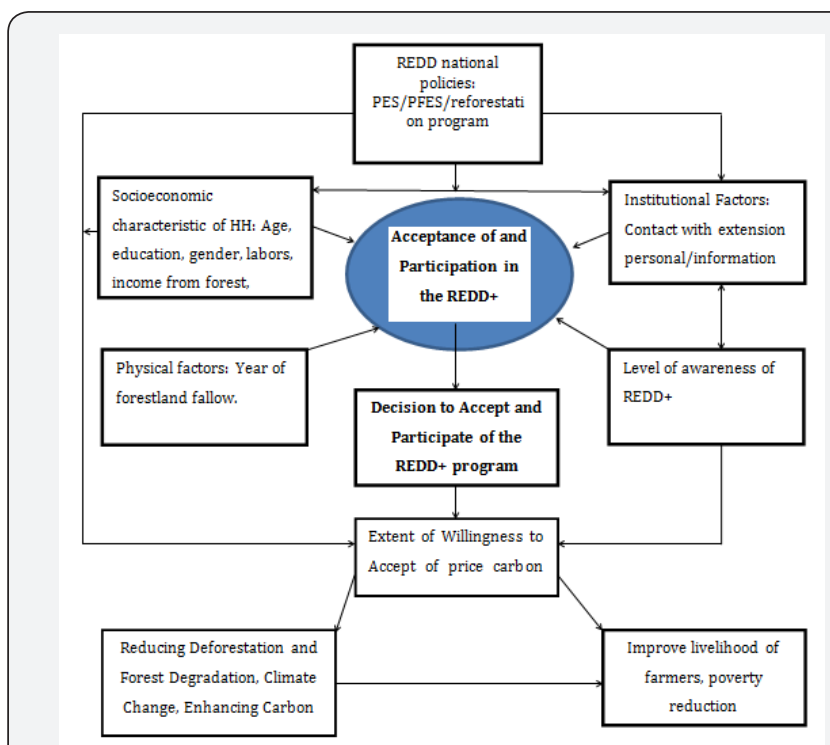

Figure 1: Framework for determining Factors Affecting WTA Carbon Payment of the REDD+ program, Vietnam.

\section{Survey instrument design using contingent valuation method (CVM)}

Asking people directly regarding their willingness to accept/ participate in a project or a program may entail cognitive problems. It requires people to independently place the subject in perspective, including both the alternatives available and the context of all other demands on their financial means. When a person does not understand the questions, their answers could be unrealistic and not representative of their personal situation. For instance, they might say that they are prepared to accept a certain amount that is way above their available resources. Therefore, the first part of the survey questionnaire was very important in gathering vital information about the households.

Contingent Valuation Method (CVM) was used to determine the willingness to accept (WTA) the carbon price payment by households and participate in REDD+ in the selected study sites. Respondents were asked how much they were willing to accept carbon price payment for them to participate in REDD+. Group discussions were conducted in each of the communes that was participated by local farmers, especially the elders, men and women 
who had participated in forest protection to determine the range of acceptable prices. The other bases for determining the bid prices of carbon were a number of previous global studies on carbon price and findings of Suyanto, et al. [11] in their research on the opportunity costs of emissions caused by land-use changes of 4-5\$/ $\mathrm{tCO}_{2}$ as well as the pre-interviews with 20 households in the two communes.

After presenting the scenarios on bidding price in the group discussions, WTA questions were posed using the single-bounded dichotomous choice. Respondents were asked directly the question "Would you like to participate in the REDD+ program? If YES, How much would you be willing to accept for this price level of carbon given a certain carbon price level?" The questioning was stopped once the respondents said that he/she was willing to accept a certain price to participate in the REDD+ program. In this format, respondents only had to make a judgment about a given carbon price, similar to when they would decide whether or not to accept a certain price.

The questionnaire was divided into 6 sections:

a. Identification and knowledge about REDD+.

b. Existing situation regarding REDD+ in the area.

c. Household's expectation.

d. Basic information of the household.

e. Willingness-to-accept for carbon payment.

f. Poverty and food security status.

Bid prices for WTA elicitation were determined through 2 focused group discussions (FGDs) using the Delphi method and preinterviews with 20 households in the two communes. Bids were set at $70,000,120,000,130,000,160,000,180,000$ and 250,000 VND per ton of $\mathrm{CO}_{2}$ per year. The 300 household respondents were randomly divided equally among the 6 bid prices (70,000VND, 120,000VND, 130,000VND, 180,000VND, 160,000VND and 250,000 VND).

\section{Analysis Tools}

The logit model was used to determine the factors affecting the decision of forest landowners to join/participate in the REDD+ program while the contingent valuation model was used to determine the forest landowner's willingness to accept (WTA) the carbon price to participate in the REDD+ program.

Correlation analyses were also done to check the correlation that may exist between the variables. Logistic regression allows for Table 1: Definition of Variables in the Empirical Logit Model.

\begin{tabular}{|c|c|c|c|}
\hline Variables & Definition & Measurement/Unit & Expected Sign \\
\hline \multicolumn{3}{|c|}{ Dependent Variable } \\
\hline \multirow{2}{*}{ Decision } & Decision of forest land owner & 1 = participate in REDD+; & 0 = not participate REDD+ \\
\hline \multicolumn{2}{|c|}{ Independent Variable } \\
\hline
\end{tabular}

estimating the probability that an event will occur or not through the prediction of a binary dependent outcome in a set of independent variables. The maximum willingness to accept question for a household is regressed against its socio-economic characteristics Ramadhan [12].

The empirical binary logit model is used as follows:

DECISION $=$ Ln $=\beta 0+\beta 1 \mathrm{BID}+\beta 2 \mathrm{AGE}+\beta 3 \mathrm{EDU}+\beta 4 \mathrm{SEX}+$ $\beta 5$ NFINC $+\beta 6$ LABOUR $+\beta 7$ INFOR $+\beta 8$ FLAND $+\beta 9$ AWARE + $\beta 10 F Y E A R+\beta 11$ PFES + ui

Where: Pi is probability of the forest landowners in participating in REDD+ program

For other indicators in the logit model are explained as follows:

a. $\quad \mathrm{Pi}$ is the probability of participating in forest management program, and (1-Pi) is the probability of non-participating in forest management program.

b. $\quad \beta 0$ is intercept of the model

c. $\quad \beta \mathrm{i}(\mathrm{i}=1$ to 11$)$ are coefficients of dependent variable in the binary logit model.

d. ui is the error term of the model.

After estimating the coefficients of the binary logit model above, the marginal effect is used to determine the effects of the factors (personal factor, institutional factor, physical factor, and economic factors) on the farmers' probability of participating in the forest management program. According to Green (2003), the marginal effect is determined by the following formula:

From the logit model:

$\operatorname{Pi}(\mathrm{Y}=1 / \mathrm{X})=(1)$

Where:

$\mathrm{Pi}$ is probability of the case $\mathrm{Y}=1$

$\mathrm{X}$ is matrix of independent variables (factors affecting)

$\beta$ is matrix of parameters

From the logit model above, we can determine the marginal effect (ME) as following formulation: (2) Where: $\mathrm{X}$ is independent variables matrix in logit model (factors affecting)

$\beta$ is matrix of parameters in logit model

Both coefficients of the binary logit model and marginal effects were estimated by STATA 14 program. 
Agricultural Research \& Technology: Open Access Journal

\begin{tabular}{|c|c|c|c|}
\hline Bid & Willingness to accept carbon payment price & Thousand VND & + \\
\hline Age & Age & Years & - \\
\hline Edu & Education & Years & + \\
\hline Sex & Gender of respondent & $1=$ male $; 0$ = female & \\
\hline Nfinc & Non timber forest products income & Thousand VND & + \\
\hline Labor & Family labor supply & Labor & + \\
\hline Infor & Information accessibility of REDD+ & $1=$ yes; $0=$ no & + \\
\hline Fland & Forest land area & На & + \\
\hline Aware & Awareness of REDD+ & $\begin{array}{l}\text { Classify in } 5 \text { levels ( } 5=\text { extremely } \\
\text { important, } 4=\text { very important, } 3= \\
\text { moderately important, } 2=\text { slightly } \\
\text { important, } 1=\text { not at all important) }\end{array}$ & + \\
\hline F year & Years of fallow land & Years & + \\
\hline Pfes & Payment from forest environmental services & Thousand VND & + \\
\hline
\end{tabular}

The variables of logit model are descript in the (Table 1). The dependent variable (y) or decision making of farmers is explained by the two value 1 and 0 where $\mathrm{y}=1$ is farmer willingness to participate in REDD+ at given bid price of carbon whereas $y=0$ means farmer do not participate in REDD+.

To estimate the mean minimum WTA, logistic regression was used in accordance with the formula proposed by Hanemann (1994), the mean minimum WTA was computed as the formula below:

(3) where $\beta$ is the coefficient of the bid price; and $\alpha$ is constant in the logistic model if there are no additional independent variables, or the sum of the estimated constant plus the sum of all other independent variable coefficients multiplied by their means (Donovan and Nicholls 2003), with

(4)Where is the constant of the logistic model and the's do not include the bid price coefficient.

\section{Results and Discussion}

\section{The study area}

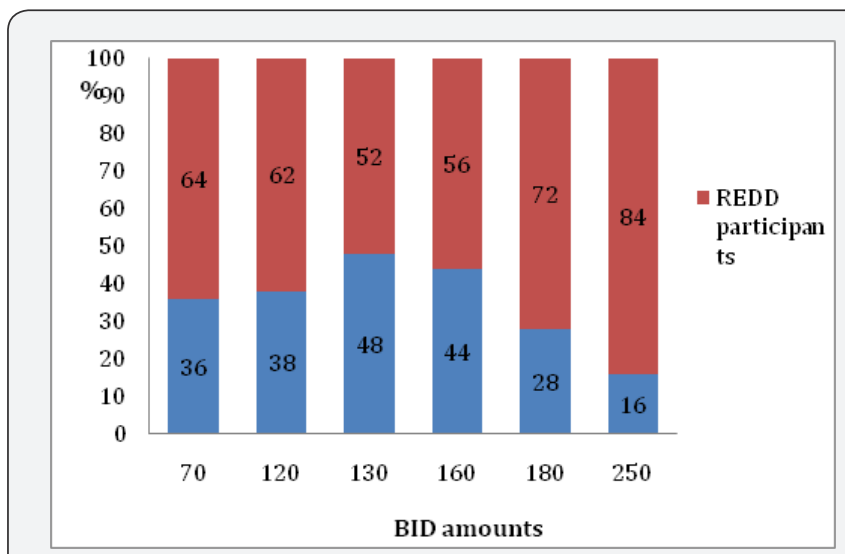

Figure 2: Distribution of respondents by different bid amounts.

Con Cuong is one of the mountainous districts in Nghe An province. It is composed of 13 administrative units, including one town and twelve communes. Located in the western part of Nghe
An, Con Cuong borders the districts of Anh Son district on the southeast, Tan Ky and Quy Hop on the northeast, and Tuong Duong on the northwest (Figure 2). In 2014, the total population of Con Cuong, composed mainly of Thai, Kinh, Dan Lai, and Tay groups, was estimated at 69,773 . Of these, $49.95 \%$ were males and $50.05 \%$ were females.

Table 2: Socio-demographic Characteristics of Con Cuong District, Nghe An Province, Vietnam, 2016.

\begin{tabular}{|c|c|c|}
\hline \multirow[b]{2}{*}{ ITEMS } & \multicolumn{2}{|c|}{ Whole District } \\
\hline & No (person) & Percent (\%) \\
\hline Total & 69,773 & 100 \\
\hline \multicolumn{3}{|c|}{ Distribution by } \\
\hline \multicolumn{3}{|l|}{ gender } \\
\hline Male & 34,852 & 49.95 \\
\hline Female & 34,921 & 50.05 \\
\hline Total labor & 43,734 & 100 \\
\hline Male & 22,304 & 51 \\
\hline Female & 21,430 & 49 \\
\hline \multicolumn{3}{|c|}{ Distribution by area } \\
\hline Rural & 40,541 & 92.7 \\
\hline Urban & 3,193 & 7.3 \\
\hline Total households & 15,820 & \\
\hline
\end{tabular}

\section{Source: Con Cuong Statistic Department, 2016.}

The total number of households in the district was 15,820 (Table 2). Total labour force, composed of individuals aged 18 to 60 years, was estimated at 43,734 , comprising $62.78 \%$ of the district's total population. Male labour comprised $51 \%$ of total labour force 
in the district. Majority of the labour force were untrained and had very low educational levels. In addition, most of the labour came from rural areas (92.7\%). This poses a major constraint to the district's economic development.

The total land area of Con Cuong is $173,831.12$ ha, of which $94.61 \%(164,460.42 \mathrm{ha})$ are agricultural lands. The district devotes 10,145 ha to agricultural production, accounting for $6.17 \%$ of agricultural lands, while forestland occupies 154,262 ha or $93.8 \%$ of agricultural lands. Meanwhile, non-agricultural land, including construction land, roads, and residential land, occupies 2,942.98 ha (1.69\%), while unused land covers 6,427ha (3.7\%) (Table 3).

Table 3: Current land use of Con Cuong District, Nghe An Province.

\begin{tabular}{|c|c|c|c|}
\hline & Land Use Type & Area (ha) & (\%) \\
\hline I & Total natural land & $\mathbf{1 7 3 , 8 3 1 . 1 2}$ & $\mathbf{1 0 0}$ \\
\hline 1 & Agricultural land area & $164,460.42$ & 94.61 \\
\hline 1.1 & Annual crops land & $7,275.61$ & 4.42 \\
\hline 1.2 & Long-terms tree & $2,869.77$ & 1.74 \\
\hline 2 & Forestland area & $154,262.63$ & 93.8 \\
\hline 2.1 & Production land area & $60,859.80$ & 37.01 \\
\hline 2.2 & Protected forest area & $19,134.00$ & 11.63 \\
\hline 2.3 & Special use forest area & $74,268.83$ & 45.16 \\
\hline 3 & Aquaculture land area & 52.41 & 0.03 \\
\hline II & Non-agricultural land area & $2,942.98$ & 1.69 \\
\hline III & Unused land area & $6,427.72$ & 3.7 \\
\hline
\end{tabular}

Source: Con Cuong People Committee, 2016.

REDD+ pilot in Con Cuong. REDD+ was implemented in Con Cuong district under the LEAF project organized by SNV and research activities conducted by CARES-VNUA from 2011 to 2013. The outcome of the project, however, was deemed insufficient, since the local people had not benefited from the REDD+. Local people were less interested in REDD+ compared to PFES and forest protection program. This points to a limited understanding of REDD+ at the village level as it is unclear how benefits of emission reduction can be achieved and shared among stakeholders. Currently, only the State Forest Company has authority to implement REDD+. However, there is a conflict of interest since the purpose of REDD+ is to address carbon emission while the company annually logs timber and contribute to the carbon emissions.
Con Cuong district is chosen as a pilot for the national REDD+ program, which is reported in Nghe An's Provincial REDD+ Action Plan (PRAP). The priority districts in Nghe An Province for REDD+ are Con Cuong, Anh Son, Ky Son, Nghia Dan, Que Phong, Quy Chau, Quy Hop, Tan Ky, Thanh Chuong, Tuong Duong. The two study sites, Luc Da and Chi Khe communes, were designated as pilot sites for the national REDD+ in Con Cuong district. In September 2015, the REDD + committee for Nghe and was established based on Decision No. 4308 issued by Nghe An People's Committee on 24/9/2015. However, after a year, Nghe an has just finished the draft of the PRAP for the period from 2016 to 2020. To date, Con Cuong district has not yet implemented the national REDD+ program.

The total area cultivated by participating households in both Chi Khe and Luc Da communes was 6.67 ha, more than those of nonparticipating households at 3.46 ha (at $5 \%$ probability level). Other land areas of participating households such as those cultivated for bamboo, acacia, and upland rice were also more than those of nonparticipating households. This is attributed to the fact that, in the case of participating households, these areas can become forests in the future, which may contribute to carbon sequestration if REDD+ were implemented in the community. Most areas for acacia and bamboo are located in production forestlands (Table 2).

For the local people, the important land areas in both communes are forestland areas or secondary forest areas, which they have left fallow for about 10 years since the forestlands were distributed among the households in the communes. These forestland areas were distributed based on Degree No. 167 issued by the Prime Minister, which stipulated that swidden areas were to be left fallow for forest development and used for the REDD+ program. In general, the size of the forestland areas in Chi Khe commune is more than those in Luc Da commune. In both communes, the average forestland area of participating households was found to be 5.2 ha, larger than the area of non-participating households at 2.17 ha.

The average number of years that the areas were left fallow was computed at 6.57 and 3.68 years for the participating and nonparticipating households, respectively. During these fallow years, the forestlands had big trees and were dense with brush and small trees. Forestland areas were protected by individual households and were not allowed to be cut for timber except for house construction. Also, distance from home to forest was significantly different among the participants and non-participants of the REDD+ program.

The forest area of most local people not participating in the REDD+ is closer to the village than the non-participants. As such, they would plant industrial trees such as acacia that provide higher financial returns than participating in the program. On the other hand, it would be difficult to visit and not financially viable to plant acacia trees in the forest areas located far from the village. It would normally take non-participants 0.86 hours to reach their forestland areas in contrast to the participants that on the average would take 1.12 hours (Table 4). 


\section{Agricultural Research \& Technology: Open Access Journal}

Table 4: Land use of respondent households in Chi Khe and Luc Da communes, Con Cuong district, Nghe An province, 2016.

\begin{tabular}{|c|c|c|c|c|c|c|c|c|c|}
\hline & \multicolumn{3}{|c|}{ Chi Khe } & \multicolumn{3}{c|}{ Luc Da } & \multicolumn{3}{c|}{ Total } \\
\hline & $\mathbf{R}$ & N-R & DIFF & R & N-R & DIFF & R & N-R & DIFF \\
\hline Paddy rice (ha) & 0.16 & 0.15 & $0.01^{\text {ns }}$ & 0.47 & 0.47 & $0.00^{\text {ns }}$ & 0.31 & 0.33 & $0.02^{\text {ns }}$ \\
\hline Uplandrice (ha) & 0.3 & 0.25 & $0.05^{\text {ns }}$ & 0 & 0 & $0.00^{\text {ns }}$ & 0.16 & 0.11 & $0.05^{\text {ns }}$ \\
\hline Maize (ha) & 0.12 & 0.21 & $0.09^{\text {ns }}$ & 0.17 & 0.13 & $0.04^{\text {ns }}$ & 0.14 & 0.17 & $0.03^{\text {ns }}$ \\
\hline Acacia (ha) & 0.56 & 0.36 & $0.20^{\text {ns }}$ & 0.41 & 0.25 & $0.16^{\text {ns }}$ & 0.49 & 0.3 & $0.19^{\text {ns }}$ \\
\hline Bamboo (ha) & 0.31 & 0.36 & $0.05^{\text {ns }}$ & 0.26 & 0.2 & $0.06^{\text {ns }}$ & 0.28 & 0.27 & $0.01^{\text {ns }}$ \\
\hline Cassava (ha) & 0.03 & 0.08 & $0.05^{\text {ns }}$ & 0.17 & 0.13 & $0.04^{\text {ns }}$ & 0.1 & 0.11 & $0.01^{\text {ns }}$ \\
\hline Total land (ha) & 7.46 & 3.67 & $3.79^{* * *}$ & 5.78 & 3.29 & $2.49^{* * *}$ & 6.67 & 3.46 & $3.20^{* * *}$ \\
\hline
\end{tabular}

Note: R: REDD+ participants; N-R: Non-REDD+ participants

${ }^{*},{ }^{* *},{ }^{* * *}$ are statistically significant at $10 \%, 5 \%$, and $1 \%$, respectively ns: non-significant.

A comparison of income sources by household groups in both communes is presented in (Table 5). It was found that the total income of participating households in both Chi Khe and Luc Da commune was higher than those of non-participating households.
The average income of households that participated in REDD in Chi Khe and Luc Da was 16.63 million VND/year and 15.42 million VND/year, respectively. The non-participating group, on the other hand, earned 15.01million VND/year and 14.48 million VND/year, respectively. The t-test conducted confirmed that the difference was statistically different at 10 percent significance level between participating and non-participating groups.

Table 5: Forest land area, years of fallow, and travel time to the forest of respondents in Chi Khe and Luc Da communes, Con Cuong district, Nghe An province, 2016.

\begin{tabular}{|c|c|c|c|c|c|c|c|c|c|}
\hline Forest Land Area & \multicolumn{3}{|c|}{ Chi Khe } & \multicolumn{3}{c|}{ Luc Da } & \multicolumn{3}{c|}{ Total } \\
\hline & R & N-R & DIFF & R & N-R & DIFF & R & N-R & DIFF \\
\hline Forestland(ha) & 5.99 & 2.27 & $3.72^{* * *}$ & 4.3 & 2.1 & $2.2^{* * *}$ & 5.2 & 2.17 & $2.85^{* * *}$ \\
\hline Number of years since last cutting (year) & 7.16 & 3.88 & $3.28^{* * *}$ & 5.92 & 3.53 & $2.39^{* * *}$ & 6.57 & 3.68 & $2.89^{* * *}$ \\
\hline Walking hours to the forest (hour) & 1.2 & 0.79 & $0.41^{*}$ & 1.03 & 0.91 & $0.12 \mathrm{~ns}$ & 1.12 & 0.86 & $0.26^{*}$ \\
\hline
\end{tabular}

Note: R: REDD+ participants; N-R: Non-REDD+ participants

${ }^{*},{ }^{* *},{ }^{* * *}$ are statistically significant at $10 \%, 5 \%$, and $1 \%$, respectively ns: non-significant.

It is interesting to note that off-farm income of participating households in Chi Khe was higher than those of non-participating households at 3.01 million VND and 2.4 million VND, respectively, while in Luc Da these amounts to 2.68 million VND and 3.06 million VND/year, respectively. This can be attributed to the fact that not many households in Luc Da commune earn from off-farm jobs. This means that the time people in Luc Da devote to look for jobs significantly reduce their time for protecting the forests. In Chi Khe, on the other hand, because villagers live near the road, they can get off-farm jobs easily while managing to spend time for forest protection.

Income from forests, including those from NTFPs, timber logging, and PFES is the major consideration in the decision to participate or not in REDD+. This is because they think that protecting the forest will bring them more benefits from nontimber forest products (NTFPs). A comparison of income derived from forests by the participating group has shown that participating households in Chi Khe commune have higher incomes than their counterparts in Luc Da commune. The reason is that the forest area managed by participants in Chi Khe is larger than in Luc Da. Another reason is that a number of households in Chi Khe commune receive payment for environmental services from the HPP.

Table 6: Income sources of respondent households in Con Cuong district, Nghe An province, Vietnam, 2016 (Unit: million VND/year).

\begin{tabular}{|c|c|c|c|c|c|c|c|c|c|}
\hline Sources of Income & & Chi Khe & & & Luc Da & & & Total & \\
\hline & $\mathbf{R}$ & N-R & DIFF & $\mathbf{R}$ & N-R & DIFF & $\mathbf{R}$ & N-R & DIFF \\
\hline Annual Crop Income & 4.55 & 5.59 & $1.04^{\mathrm{ns}}$ & 4.45 & 3.8 & $0.64^{\mathrm{ns}}$ & 4.5 & 4.6 & $0.09^{\mathrm{ns}}$ \\
\hline Livestock Income & 4.72 & 4.25 & $0.47^{\mathrm{ns}}$ & 5 & 4.77 & $0.22^{\text {ns }}$ & 4.85 & 4.54 & $0.3^{\mathrm{ns}}$ \\
\hline Income from Forest & 4.35 & 2.76 & $1.73^{* * *}$ & 3.29 & 2.85 & $0.46^{*}$ & 3.85 & 2.81 & $1.13^{* * *}$ \\
\hline Off-farm Income & 3.01 & 2.4 & $0.60^{\mathrm{ns}}$ & 2.68 & 3.06 & $0.38^{\text {ns }}$ & 2.85 & 2.77 & $0.08^{\mathrm{ns}}$ \\
\hline Total Income & 16.63 & 15.01 & $1.62^{\mathrm{ns}}$ & 15.42 & 14.48 & $0.94^{\mathrm{ns}}$ & 16.06 & 14.72 & $1.34^{\mathrm{ns}}$ \\
\hline
\end{tabular}


Note: R: REDD+ participants; N-R: Non-REDD+ participants ${ }^{*},{ }^{* *},{ }^{* * *}$ are statistically significant at $10 \%, 5 \%$, and $1 \%$, respectively ns: non-significant.

Thus, for the participating group, income from the forest is significantly higher at $1 \%$ than the non-participating group. Livestock income was also higher for the participating group since most large animals such as buffaloes and cows are protected in the forestland areas where they are allowed to freely graze. The fences that farmers erect around the forest areas and the dense thicket of the forest area provide the protection for the animals (Table 6).

\section{Factors affecting willingness to accept}

Respondent's WTA bid price is a measure of the value they attribute to the carbon credit of the REDD+ program. The bid price indicates the amount that the respondent is willing to accept in exchange for selling carbon credit. For the purpose of this study, 300 respondents in the two communes were interviewed using prepared questionnaires. Majority of respondents agreed to accept the bid prices of carbon credit that were randomly assigned to them (195 respondents or 65\%). In contrast, 105 respondents or $35 \%$ stated that they were unwilling to accept the prices offered and participate in the REDD+ program (Table 7).

Table 7: Overall distribution of respondents within the sample population with positive and negative WTA.

\begin{tabular}{|c|c|c|}
\hline WTA & Freq & \% \\
\hline REDD+ participants (Yes to the Bids) & 195 & 65 \\
\hline Non-REDD+ participants (No to the Bids) & 105 & 35 \\
\hline Total & 300 & 100 \\
\hline
\end{tabular}

Source: Primary Survey, 2016.

Figure 2 shows that about $84 \%$ of respondents agreed to participate in REDD+ at the highest bid level (250,000 VND) or US $\$ 11.36 /$ tCO2. Meanwhile, $72 \%$ of respondents said they were willing to participate in the program when carbon price is fixed at 180,000 VND or US $\$ 8.18 / \mathrm{tCO} 2$. On the other hand, $64 \%$ and $62 \%$ of respondents agreed to a carbon price set at 70,000VND and 120,000 VND (or US\$ 3.18 and US\$ 5.45, respectively). About 52\% of respondent agreed with the bid amount of 130,000VND or US\$ $5.9 / \mathrm{tCO} 2$ and $56 \%$ of respondents were willing to accept a bid price of $160,000 \mathrm{VND}$ or US $\$ 7.27 / \mathrm{tCO} 2$.

In this study, the decisions of households in the two communes whether or not to participate in the REDD+ program were hypothesized to be influenced by 11 explanatory variables. These variables were based on the review of literature of factors affecting WTA bids for carbon prices. The REDD+ decision model used for the study sites is a binary logit model, which assigns a value equal to 1 for accepting selling carbon credit and 0 for not accepting selling carbon credit from the REDD+ program. The characteristics of the variables are presented in Table 8.
Table 8: Descriptive statistics of the independent variables of the empirical logit model.

\begin{tabular}{|c|c|c|c|c|}
\hline Variable & Mean & Std. Dev. & Min & Max \\
\hline BID (1000VND) & 151.67 & 55.9 & 70 & 250 \\
\hline AGE (years) & 44.91 & 12.27 & 19 & 84 \\
\hline EDU (Education level - years) & 5.54 & 3.48 & 0 & 19 \\
\hline SEX (Male: 1, Female:0) & 0.57 & 0.5 & 0 & 1 \\
\hline LABOR (labor force - person) & 2.58 & 0.83 & 1 & 6 \\
\hline $\begin{array}{c}\text { INFOR (Information } \\
\text { accessibility - 1: yes; 0: } \\
\text { otherwise) }\end{array}$ & 0.46 & 0.5 & 0 & 1 \\
\hline FLAND (Forestland areas - ha) & 4.14 & 3.34 & 0 & 20 \\
\hline $\begin{array}{l}\text { AWARE: Awareness of REDD (5 } \\
\text { = extremely important, } 4=\text { very } \\
\text { important, } 3=\text { moderately } \\
\text { important, } 2=\text { slightly } \\
\text { important, } 1=\text { not at all } \\
\text { important) }\end{array}$ & 3.15 & 1.16 & 1 & 5 \\
\hline $\begin{array}{c}\text { FYEAR (Year of fallow land - } \\
\text { year) }\end{array}$ & 5.55 & 4.12 & 0 & 15 \\
\hline $\begin{array}{l}\text { NFINC (Non-timber forest } \\
\text { income-mil.VND) }\end{array}$ & 3.02 & 2.38 & 0.5 & 21 \\
\hline $\begin{array}{l}\text { PFES (payment from forest } \\
\text { environmental services - } \\
\text { 1000VND }\end{array}$ & 468.12 & 505.05 & 0 & 2,200 \\
\hline
\end{tabular}

Source: Primary Survey, 2016.

The average of bids is 151.67 thousand VND, which ranged from 70 to 250 thousand VND. The average age of respondents is 45 years old, with the oldest aged 84 years old and the youngest aged 19 years. Because of the remoteness of the area, most respondents were not able to go to school. Each respondent finished his/her academic school program within 5.54 years of attending school. Only one respondent finished studying at the university, and he is now an officer at the Chi Khe commune. Meanwhile, many respondents could not finish Grade 1 level. The average number of family labour per household was 3 with a maximum of 6 and a minimum of 1 . As mentioned by respondents, labour is a crucial factor in forest management and protection, since forests are often located very far from their homes. Moreover, it is often the younger and stronger persons who are able to participate in such programs.

Forestland area owned by individual households will affect the decision whether or not to participate in REDD+, since the program will pay for forest carbon sequestration. Each household owns an average of 4.14 ha; with the highest area owned is 20 ha of secondary forests, while some households do not own forestland area. While it may appear as if these households do not have 
forestlands to utilize, in reality, they actually have since households split forestland among family members. Thus an individual can still have a portion of forestland to protect, although this is not indicated in certification or red book title.

To gauge respondents' awareness on REDD+, they were asked what they think about the program, which involves its contribution or importance to the household's income or to environmental issues. Responses ranged from (1) for not important at all to (5) for extremely important. Additionally, fallow period of the land is important in household decision to participate in REDD+. The forestland area in both communes was fallowed for 5.55 years since the local people stopped practicing shifting cultivation. Information on forest fallow land included the size and density of tree growth on the forestland.

The largest area of forestland owned by a household is 20 ha, which was consolidated from forestland bought from other households. Income from non-timber forest products amounted to 3.02 million VND per year while PFES contributed about 0.468 million VND. The highest amount of PFES is 2.2 million VND per year, which belonged to a household in Chi Khe commune where there is a hydropower plant.

\section{Results of logit model}

A logistic regression analysis was used to identify significant variables affecting the respondents' willingness to participate in the REDD+ program. The estimated coefficients and marginal effects of the empirical logit model are shown in Table 8. A likelihood ratio test was run to measure the goodness of fit of the model in the REDD+ participation decision. Since the likelihood function is a measure of how well $\beta$ explains the given sample dependent variables, it was done to test the hypothesis that the variable in the model have no effect upon the value of the dependent variable. This is denoted by:

$$
\text { Ho }=\beta 1=\beta 2=\beta \mathrm{k}=0
$$

Ha: some $\beta \mathrm{i} \neq 0$

With a likelihood ratio chi2 (11) of 137.29 and a p-value of 0.0000 , we can reject the null hypothesis that all independent variables of the logit model are zero. This implies that the expected value estimating the probability of the household to participate was explained by the significant explanatory variables under the condition of rejecting the null hypothesis. The Pseudo R2 (0.3534) means that the model is able to explain 35.34 percent of the changes in the probability of households participating in the REDD+.

Unlike the ordinary least square estimate (OLS), the maximum likelihood estimate or logit model cannot be treated as estimate of the change in the dependent variable from a unit change in any independent variable coefficients. The marginal effects of change in the independent variables were used to explain their effects on the dependent variable Green, [13].

Based on the results of the logistic analysis (Table 9), the empirical model of the study is specified below:
Table 9: Estimated coefficients of logit model for decision of household to participate in the REDD+ program, Con Cuong district, Nghe An, Vietnam $(n=300)$.

\begin{tabular}{|c|c|c|c|c|}
\hline Variable & Coefficient & Z-Test & Me(Dy/Dx) & Z-Test \\
\hline intercept & -5.881 & -4.84 & - & - \\
\hline BID & 0.006 & 2.28 & $0.0013^{*}$ & 2.27 \\
\hline AGE & -0.033 & -2.47 & $-0.006^{*}$ & -2.48 \\
\hline EDU & 0.007 & 0.16 & $0.001 \mathrm{~ns}$ & 0.16 \\
\hline SEX & 0.912 & 2.71 & $0.181^{* *}$ & 2.68 \\
\hline LABOR & 0.595 & 2.59 & $0.115^{* *}$ & 2.63 \\
\hline INFOR & 0.485 & 1.49 & $0.093 \mathrm{~ns}$ & 1.51 \\
\hline FLAND & 0.387 & 4.72 & $0.075^{* * *}$ & 4.97 \\
\hline AWARE & 0.715 & 4.77 & $0.138^{* * *}$ & 4.76 \\
\hline FYEAR & 0.071 & 1.55 & $0.013 \mathrm{~ns}$ & 1.53 \\
\hline NFINC & 0.234 & 2.88 & $0.045^{* * *}$ & 2.91 \\
\hline PFES & 0 & 0.37 & $0.000 \mathrm{~ns}$ & 0.37 \\
\hline
\end{tabular}

Note: ${ }^{* * *},{ }^{* *}$ and * are significant at $1 \%, 5 \%$ and $10 \%$ of probability level, respectively

ns: is non-significant; and ME is marginal effect

LR chi2 $(11)=137.29$

Log likelihood $=-125.58$

Prob $>$ chi $2=0.0000$

Pseudo $\mathrm{R}^{2}=0.3534$

$\mathrm{DECISION}=\mathrm{Ln}=-5.881+0.0068^{*} \mathrm{BID}-0.033^{*} \mathrm{AGE}+0.007 * \mathrm{EDU}$ $+0.912^{*}$ SEX + 0.595*LABOUR + 0.485*INFOR + 0.387*FLAND + $0.715^{*}$ AWARE $+0.071 *$ FYEAR $+0.234^{*}$ NFINC $+0.000 *$ PFES

Given the coefficients in Table 8, there are seven factors that clearly affect the decision of household to participate in the REDD+ program. These are the bid level of carbon price, age of respondent, sex, labour force, forest land areas, awareness of REDD+, and nontimber forest products income. Only the coefficient variable age of respondent has a negative sign and is statistically significant at $10 \%$ probability level. This means that younger farmers tend to participate more in REDD+ program, ceteris paribus.

This can be explained by the fact that households in Chi Khe and Luc Da communes have less chance of working outside the villages so that farming and forest activities are the main occupation, especially of younger people. Older people tend to work at farms nearby their house because the forests are often far from their homes and are difficult to access. Results indicate that a one-year increase in age of respondents will reduce the probability of the household to participate in the REDD+ program by 0.006 or 0.6 percent.

The coefficient bid price of carbon is significant and positive, which is consistent with prior studies. The positive coefficient of bid price indicates that WTA increases as the bid amount increases at $10 \%$ probability level.

Meanwhile, the sex factor is positive and significant at $5 \%$ probability level, which means that there is a clear difference in decision-making between men and women regarding participation 
in the REDD+ program. In mountainous regions, men play an important role in hard work, especially since men participate mostly in forest activities such as timber logging, patrolling and protecting forests, while women only participate in collecting nontimber forest products such as bamboo shoots.

In the family, men are the decision-makers when it comes to all farming activities, including forest management. An important factor affecting the decision-making of villagers to participate in REDD+ is labour force in the household. The marginal effect coefficient is 0.115 , which shows that a one-unit increase in labour force of the household increases the probability of participating in REDD+ program by 11.5 percent, ceteris paribus.

The more labour there is in the household, the greater the probability that they will participate in REDD+. This is consistent with the fact that older people are seldom involved in forest protection and management. Because REDD+ requires participants to be involved in measuring carbon sequestration, as well as checking and monitoring forest status every month/year, only individuals of labour age can participate in forest protection and management. It does not come as a surprise that the forest land area of households is a factor affecting the decision of villagers in participating in the REDD+. The positive relationship between forest land area and decision to participate in REDD+ means that villagers are more likely to participate if their forestland increased. The probability of participation increases by 7.5 percent for every additional hectare of forestland. This is because the REDD+ will pay for every ton of carbon sequestration from forests. No forest land area means no payment from REDD+.

It is interesting to note that the villagers' awareness of REDD+ significantly affects the decision to participate in the program. The greater the knowledge of local villagers on REDD+, the more likely they are to be involved in the program. Most respondents reported that protecting the forest is important to their livelihoods and to addressing environment issues. While the term REDD+ is unfamiliar to most respondents, the concept of protection forest activities is very popular among the villagers. Explanations on the meaning of REDD+ and its role and benefits to the local people are important, and will thus affect their decision-making. This is an important issue for local authorities and REDD+ policymakers.

Non-timber forest products income is another factor contributing to the decision of villagers to participate in the REDD+ program. The marginal effect of this variable is positive and significant at $1 \%$ probability level. This implies that households having higher income from NTFPs tend to be more likely to participate in REDD+ than other households. Coefficient of the variable NFINC indicates that a one-unit increase in income from non-timber forest products increases by $4.5 \%$ the probability of villagers participating in REDD+.

Protecting the forest well will increase NTFPs such as honey and bamboo shoots. Yet protecting forests means that local villagers are not allowed to log timber and cut trees in the forest. Income from forests will be reduced if REDD+ were to be implemented; thus, income from non-timber forest products such as medical plants, brush, honey and bamboo shoots are important contributions to household income.

Four variables (education level, information accessibility, years of fallow period of land, and payment from forest environmental services) were found to be not significant in the model. While education level of respondent is expected to have positive influence on the decision of villagers to participate in REDD+, results show that this factor is insignificant, implying that the effect of education level on decision-making in REDD+ participations is not clear. This can be attributed to the fact that upland people are not well educated, and most of them have attained very low education level, which does not vary among participants or non-participants in the REDD+ program.

Access to information about REDD+ of villagers was also found non-significant when it comes to decision-making in REDD+ participation. Limited access to information from outside the two communes could explain this result. For example, Moi village in Luc Da commune is very hard to access by motorbike. Villagers from Moi often had to walk to the commune centre, and during the rainy season they do not go out of their village because the road is very hard to navigate. Although some posters related to forest protection and introduction to REDD+ were posted in the commune centre, the local people never saw them or could not understand the words. Information from mass media or radio cast is not effective either, because the centre is very far from the villages.

While it is also expected that the length of fallow period of land and payment from forest environmental services would be positive and have significant influence on the decision to participate in REDD+ program, results prove otherwise. These areas have been allowed to fallow to stimulate the growth of secondary forests. However, after the allocation process, local villagers are still practicing shifting cultivation in the areas. Through government efforts, shifting cultivation in the communes has stopped since 2010.

At the time of the interviews, the average forest length of fallow period in the communes is almost six years. Most trees in the forest are still small, with low carbon sequestration capacity; therefore, this variable does not affect the decision of local villagers to join the REDD+ program. The PFES variable also has non-significant relationship with the decision to participate. This is because PFES is paid based on forest areas affected by hydropower plants. Villagers in Chi Khe have been receiving PFES from HPP while the Luc Da commune has not yet received payment. Households that enter into contract to protect the forests covered by the Pu Mat National Park also get payment, although not all households in the communes have been paid by the national park.

\section{Determination of willingness to accept}

Determining the villagers' mean willingness to accept carbon price to participate in REDD+ is the objective of this study. Equations 
(3) and (4) were used to determine the mean WTA carbon price in participating REDD+ as presented in Table 10. Results show that the mean maximum WTA for a ton of carbon is equivalent to $114,400 \mathrm{VND} / \mathrm{t} \mathrm{CO}_{2}$ or US $\$ 5.2 / \mathrm{t} \mathrm{CO}_{2}$, higher than the carbon price used a previous studies by Suyanto (15) (4- US\$ 5/ $\mathrm{CO}_{2}$ ).

Table 10: Values comprising the constant $\alpha$ for the computation of mean WTA using equations 3 and 4 .

\begin{tabular}{|c|c|c|c|}
\hline Variable & Coeff (1) & Mean (2) & $\begin{array}{l}\text { Product } \\
=(1) \times(2)\end{array}$ \\
\hline Constant & -5.881 & - & -5.881 \\
\hline AGE & -0.033 & 44.91 & -1.481 \\
\hline EDU & 0.007 & 5.54 & 0.041 \\
\hline SEX & 0.912 & 0.57 & 0.52 \\
\hline NFINC & 0.234 & 3.02 & 0.707 \\
\hline LABOR & 0.595 & 2.58 & 1.535 \\
\hline INFOR & 0.485 & 0.46 & 0.223 \\
\hline FLAND & 0.387 & 4.14 & 1.602 \\
\hline AWARE & 0.715 & 3.15 & 2.251 \\
\hline FYEAR & 0.071 & 5.55 & 0.396 \\
\hline PFES & 0 & 468.12 & 0.076 \\
\hline Total $\alpha$ & & & -0.013 \\
\hline mean WTA per $\mathrm{tCO}_{2}(1000 \mathrm{VND})$ & 114.4 & & \\
\hline \multicolumn{2}{|c|}{ Total Benefit per ha/year (1000 VND) } & \multicolumn{2}{|c|}{$\begin{array}{c}=114.4 \times 14.5 \mathrm{tCO} 2 \\
=1,658.8\end{array}$} \\
\hline \multicolumn{2}{|c|}{ Total Benefit with total 16,775 ha (1000 VND) } & \multicolumn{2}{|c|}{$\begin{array}{c}=1,658.8 \times 16,775 \mathrm{ha}= \\
27,826,370\end{array}$} \\
\hline
\end{tabular}

Source: Primary Survey, 2016.

Since the forestland areas of farmers involved in the study sites are agricultural land fallowed for an average of 5.5 years, using data in (Table 11) yields a carbon sequestration equivalent of $14.5 \mathrm{t}_{2}$ per ha $($ or $=(18+11) / 2)$.

Table 11: Estimated carbon, profit by land use in Peruvian forest, Amazon.

\begin{tabular}{|c|c|c|c|}
\hline Land use & $\begin{array}{c}\text { Cstock(tC/ } \\
\text { ha) }\end{array}$ & $\begin{array}{c}\text { CO2E stock } \\
\text { (tCO } \mathbf{2} / \mathbf{h a} \text { ) }\end{array}$ & $\begin{array}{c}\text { Profitability } \\
\text { (NPV.\$/ha) }\end{array}$ \\
\hline Natural forest & 250 & 918 & 31 \\
\hline Logged forest & 200 & 734 & 300 \\
\hline Heavily logged forest & 120 & 440 & 500 \\
\hline Agroforest 1 & 80 & 294 & 300 \\
\hline Agroforest 2 & 60 & 185 & 120 \\
\hline Cocoa & 50 & 147 & 604 \\
\hline Oil palm & 40 & 183 & 245 \\
\hline Improved pasture & 3 & 11 & 618 \\
\hline Low-productivity & 2 & 7 & 336 \\
\hline pastures & 5 & 18 & 302 \\
\hline Agriculture 8-yr fallow & 3 & 11 & 409 \\
\hline
\end{tabular}

Source: Cited from: Palm, et al., 2004; White, et al., 2005.
Table 10 shows that on the average, a hectare of forest in the study site can get $1,658,800 \mathrm{VND} /$ ha or US\$ $75 /$ ha. The total forestland area of the two communes is 16,775 ha. Taking into account the amount $(1,658,800 \mathrm{VND} / \mathrm{ha})$ that can be obtained from selling carbon sequestration, a total of $27,826,370$ thousand VND can be obtained from the two communes or US $\$ 1.264$ million for a total of 3,341 households. This is a huge amount of money coming from the environmental budget that contributes to household income.

\section{Respondents' reasons for participation and non- participation in redd+}

Table 12: Respondents' reason for REDD+ participation and nonparticipation.

\begin{tabular}{|c|c|c|}
\hline Reasons a & Freq & \% \\
\hline $\begin{array}{c}\text { Reasons for Participation (n = 195) } \\
\text { I want the forest to be restored to its former } \\
\text { beauty }\end{array}$ & 153 & 78.46 \\
\hline $\begin{array}{c}\text { Contact with extension personal/REDD+ } \\
\text { researchers }\end{array}$ & 45 & 23.07 \\
\hline The price is relatively good & 142 & 72.82 \\
\hline It is good for the community & 52 & 26.67 \\
\hline Getting additional income for my family & 162 & 83.08 \\
\hline $\begin{array}{c}\text { Conserving the forest will benefit my children and } \\
\text { future generation }\end{array}$ & 177 & 90.77 \\
\hline Protecting my boundary forest area & 21 & 10.77 \\
\hline \begin{tabular}{c} 
Reasons for “Non-Participation" (n= 105) \\
\hline I don't have forestland
\end{tabular} & 92 & 87.62 \\
\hline Have no available labor supply & 87 & 82.86 \\
\hline I have other activities with higher income & 23 & 21.9 \\
\hline I don't know what it is. & 67 & 63.81 \\
\hline The forest is located in difficult-to-reach site & 46 & 43.81 \\
\hline Conflict between forest owners & 6 & 5.71 \\
\hline Carbon price is too low & 31 & 29.52 \\
\hline
\end{tabular}

a: Some respondents gave multiple answers

Source: Primary Survey, 2016.

Respondents who agreed to accept the given bid were asked for their reasons for consenting. Table 12 shows the frequency and percentage of respondents who answered yes and no when asked if they were willing to accept. A reason provided by $78.46 \%$ of the respondents for their willingness to participate in the REDD+ program was because it would help maintain the pristine condition of the forest. Another reason given by 142 respondents (72.82\%) was that the carbon price was sufficiently financially attractive. The highest percentage of respondents who agreed to accept stated that participation will help conserve the forests for the next generations (90.77\%).

Results indicate that local people perceive that the forests are currently being degraded and must be protected. Interestingly, forty-five respondents $(23.07 \%)$ who decided to participate in 
REDD+ have expressed to their extension officers and REDD+ that there was a great benefit derived from REDD+ to their environment and livelihoods. In fact, some respondents in the study sites were invited to participate in group discussions and individual household interviews when the CARES-VNUA and SNV organization carried out the research on REDD+ activities in the Con Cuong district in the past (2011-2014). By this means, the respondents were properly informed about REDD+ by the researchers.

There were a number of reasons why some of the respondents did not choose to participate in the REDD+ program or accept the bid prices. About $87.62 \%$ (92 out of 105) of respondents mentioned that they did not have forestland area. During the forest land distribution program in 1998, many individuals who were separated from their parents after the program lost the forestlands they were using. In practice however, when an individual separates from his/her family due to marriage, he/she is given a part of his/ her parents' forestland, although there is no official certification for the transfer of ownership. Another reason given was the lack of household family labour (82.86\%). Some $63.81 \%$ of respondents found the terms of REDD+ difficult to understand. On the other hand, $43.81 \%$ of respondents thought that their forests were too far and very hard to access. Low carbon price was also cited by 31 respondents as a reason not to participate in REDD+. Only $22 \%$ of respondents said they engage in other activities that provide them with higher income than that from forest protection.

\section{Conclusion}

Forestland area is very important to local households as income source, and also a vital condition for REDD+. The average forestland area of participating households in both Chi Khe and Luc Da communes was 5.2 ha, higher than that of non-participating households at 2.17 ha. Fallow period was about 6.57 and 3.68 years for participating and non-participating households, respectively [14-17].

Meanwhile, the total average income of households is 15.59 million VND per year, which is low compared to other communes in the district. Income from forests contributed about $22 \%$ of the total income, which is the highest after crop income and livestock production. Income from forest of households that agreed to participate in REDD+ is higher than those that refused to participate. Income, therefore, is one of the reasons that affect villagers' decision whether or not to participate in the program.

The logit model showed that the factors significantly affecting decision-making on participating in REDD+ include age of respondent, bid level of carbon price, sex of respondent, labour force, forest land areas, awareness of REDD+, and non-timber forest products income. The computed mean maximum WTA for a ton of carbon in the Con Cuong District is equivalent to $114,400 \mathrm{VND}$ or US\$5.2/tCO2, higher than that carbon price used in previous studies (US\$ 4-5/tCO2). On the average, a hectare of forest can get $1,658,800 \mathrm{VND} /$ ha or $75.4 \mathrm{US} \$ /$ ha from carbon sequestration. This would generate a social WTA per year of 22.944 billion VND or US\$
1.04 million for a total of 3,341 households in the two communes [18].

With regards to the reason for accepting or not accepting REDD+, $78.46 \%$ of respondents said they were willing to accept since REDD+ involvement will improve forest conservation and restore them to their former density. Good carbon price was also cited by 142 respondents $(72.82 \%)$ as reason for accepting the bid. The highest percentage of respondents who agreed to accept did so to conserve forests for the next generation (90.77\%). This means that the local people perceived that the forests are currently being degraded and as a result must be protected. The most common reason cited for not accepting REDD+ is that respondents do not have forestlands.

Therefore, providing more information about REDD+ to local people through workshops both at the lower government and local levels can be mutually beneficial for national REDD+ in Con Cuong district, Nghe An province. Trainings should be organized to inform both the local authorities and people about the REDD+ program. The training could include topics on monitoring the forest, measuring carbon sequestration (how to use GPS tools for monitoring the forest), forest fire control, the kind of non-timber forest products that are allowed to be collected, role of forest in relation to the livelihoods local people, environment protection and climate change mitigation.

The major recommendation is that policies should be able to consider important factors such as non-timber forest products income and forestland area. Households that earn more income from forests and forestland areas are more likely to participate in the REDD+ program. Therefore, if REDD+ will be implemented in the communities, it must be possible to allow local farmers to collect non-timber forest products from the forests. Most respondents agreed that during collection for NTFPs, they were also at the same time protecting the forest.

\section{References}

1. Van Der Werf GR, Morton DC, Sdefries R, JGJ Oliver, PS Kasibhatla, et al. (2009) $\mathrm{CO}_{2}$ Emission from Forest Loss. Nature Geoscience 2(11): 73738.

2. Komba C, E Muchapondwa (2016) An Analysis of Factors Affecting Household Willingness to participate in the REDD+ program in Tanzania. Climate and development, pp. 114.

3. IPCC (2007) contribution of Working Group III to the Fourth Assessment Report of the Intergovernmental Panel on Climate Change. Intergovernmental Panel on Climate Change, pp. 1-863.

4. LucaT, S Mahanty, H Suich (2010) Payments for Environmental Services, Forest Conservation and Climate Change: Livelihoods in the REDD? Edward Elgar, pp. 267.

5. REDD Vietnam (2012) Vietnam's opinions on REDD+ emissions reduction in the Carbon fund $4^{\text {th }}$ Meeting.

6. Righelato R, DV Spracklen (2007) Carbon Mitigation by Biofuels or by Saving and Restoring Forests? Science 317(5840): 902.

7. Angelsena CW, Gierløff AM, Beltrán, MD Elzen (2014) REDD Credits in a Global Carbon Market: Options and Impacts. TemaNord, pp. 1-105. 
8. Sohngen B, Sedjo R (2006) Carbon Sequestration in Global Forests Under Different Carbon Price Regimes. Energy Journal MultiGreenhouse Gas Mitigation and Climate Policy 3: 109-126.

9. Samuel Sp Santos, B Leimona (2012) Seeing REDD: A Microeconomic Analysis of Carbon Sequestration in Indonesia. Selected Paper prepared for presentation at the International Association of Agricultural Economists (IAAE) Triennial Conference, Foz do Iguau, Brazil.

10. Henrik L, Y Mitani (2012) Forest Owners' Willingness to Accept Compensation for Voluntary Forest Conservation: A Contingent Valuation Approach. Journal of Forest Economics 18 (4): 290-302.

11. Suyanto S, Ekadinata A, Sofiyuddin M, Rahmanullah A (2013) Opportunity Costs of Emissions Caused by Land-Use Changes. Open Journal of Forestry 4 (1): 85-90.

12. Ramadhan R S (2015) Analysis of inter-household willingness to pay for solid waste management in Mwanza city, Tanzania. Journal of Resources Development and Management 4: 57-59

13. Green W H (2003) Econometric Analysis. In: Fifth Edition. Pearson Education International. prentice Hall, pp. 1-827.

14. Townshendn T, Fankhauser S, Aybar R, Collins M, Landesman T, et al. (2013) The GLOBE Climate Legislation Study. In: Third Edition.
A Review of Climate Change Legislation in 33 Countries. Globe International, pp. 1-488.

15. Hanemann WM (1991) Willingness to pay and willingness to accept: How much can they differ? The American Economic Review 81(3): 635-647.

16. IPCC (2007) Climate Change 2007: The Physical Science Basis In: Contribution of Working Group I to the Fourth Assessment Report of the Intergovernmental Panel on Climate Change. Solomon S, et al. (Eds.), Cambridge University Press, India, pp.1- 996

17. Donovan GH, Nicholls DL (2003) Estimating consumer willingness to pay a price premium for Alaska secondary wood products.US Department of Agriculture, p. 1-14.

18. DECISION NO. 799/QĐ-TTG dated on $27 / 6 / 2012$ by the Primary Minister on approving the National Action Program on "Reduction of greenhouse gas emissions through efforts to reduce deforestation and forest degradation, sustainable management of forest resources, conservation and enhancement of forest carbon stocks" for the period 2011-2020.

\section{Your next submission with Juniper Publishers will reach you the below assets}

- Quality Editorial service

- Swift Peer Review

- Reprints availability

- E-prints Service

- Manuscript Podcast for convenient understanding

- Global attainment for your research

- Manuscript accessibility in different formats

( Pdf, E-pub, Full Text, Audio)

- Unceasing customer service

Track the below URL for one-step submission https://juniperpublishers.com/online-submission.php 